\title{
Human Rights Education Establishment for Elementary School in Kendal Regency, Central Java, Indonesia
}

\author{
Vita Santa Kusuma Chrisantina*, Sugiyo Sugiyo, Wahyu Hardyanto, Suwito Eko Purnomo \\ Educational Management Program \\ Universitas Negeri Semarang \\ Semarang, Indonesia \\ *vitasanta17@gmail.com
}

\begin{abstract}
Indonesia as a developing country has a high number of human rights violations to children. Due to the high number of human rights violations, it is needed a new system through education system. In line with United Nation recommendation about human rights education, this research has a focus on establishing human rights education model adopted from UNICEF curriculum and adjusted to ideology, philosophy and national issues. Experiment research with animation film model was made with blender $2.78 \mathrm{~b}$ application. The test was conducted to 40 (forty) elementary school teachers. The result showed that human rights education had an important role in increasing knowledge, information, skill and awareness of human rights. This research was conducted to give contribution in establishing human rights education for elementary Kendal regency school. The aim of this research was to minimize violations and human rights abuse into children in Kendal Regency.
\end{abstract}

Keywords-children violation; elementary school; human right education

\section{INTRODUCTION}

The Indonesian government's effort to promote human rights was in contrast to the phenomenon of human rights cases Annual Report of National Commission of Human Rights, 2016. There were 6.284 complaints of human rights violations (2012), 6.658 complaints (2013), 7.285 complaints (2014), 8.249 complaints (2015) and 7.188 complaints (2016) Annual Report of National Commission of Human Rights, 2016). Violence and human rights abuse to children were increase in each year. In 2011, there were 2.178 cases, 3.512 cases (2012), 4.311 cases (2013), 5.066 cases (2014) and 6.726 cases (2015) (National Commission of Children Protection, 2016).

In Central Java, there were 496 violations cases to children and woman in 2016. The number of 496 consists of $29.50 \%$ children as victims and $4.70 \%$ children as perpetrator of violence. In Kendal Regency, there were 91 violation cases (2013), 104 cases (2014), 104 cases (2015) and 108 cases (2016). Violence cases against children and woman are dominated by sexual offence. There were 60 cases (2014), 58 cases (2015) and 70 cases (2016) Therefore, Kendal Regency is categorized as violent zone of children and women.
The objectives of research are 1) analyzing human rights education at elementary school in Kendal Regency; 2) analyzing the effectiveness of animation-based education model for elementary school teachers. This research is useful to contribute human rights education to minimize children's rights violations in community.

\section{THEORETICAL}

Violence and children's rights delinquency often occur in developing countries, therefore human rights education is needed [1]. Stated that human rights education is needed to minimize children's rights violations number [2], [3].

In terms of organizing and implementing human rights education, Skinner stated that the most important thing in human rights education is reinforcement to provide strong stimulus and response [4]. Rahyubi stated that behavioral development theory will make learners become a passive person because this theory is implemented by giving drill or habituation method [5].

Wyk said that the used of cartoon as learning media could increase constructive, cooperative and collaborative learning between students [6]. Eker and Karadeniz added that cartoon as learning media could be used to increase students' achievement [7]. Jennings added that human rights education did not only need material preparation, but also teachers' preparation in teaching [8].

\section{METHOD}

The study was conducted to 40 elementary school teachers out of 5.670 teachers in Kendal Regency. Sampling technique was purposive sampling with 40 respondents from 20 subdistrict. The sample was divided into 2 groups. The study was conducted with R\&D approach. The research began with analyzing human rights issues, then created human rights material. The material was created in 16 animation film titles for 8 times meeting for treatment. The material of human rights education piloted in the form of human rights education model using cartoon as media. The cartoon contains of knowledge, information, training, skills and activity to increase concern and universal human rights respects. 
According to Law No. 39 of 1999 about human rights and Law No. 35 of 2014 about children protection, there are 31 children's rights. The children's rights are divided into 5 clusters namely 1) civil and freedom rights, 2) family and alternative nurture, 3) health and social welfare, 4) education, free time and culture activity, 5) special protection for children with special needs, dealing with legal issues, victims of violence and disaster and so forth.

Based on 5 clusters of children's right, this study used 16 animation films entitled nutritious food, vaccines is healthy, health facilities, I need birth certificate, pollution free, drug hazard, child exploitation, sexual harassment, stop bullying, stop labelling, education rights, educative punishment, let's argue and discussion, stop fighting, let's holiday and be fair.

Primary data obtained from interview, observation and questionnaires, while secondary data obtained from literature, book, annual report and article about human rights education. Data analysis in this study used to test and N-Gain value analysis

\section{RESULT AND DISCUSSION}

There was no human rights education in elementary school in Kendal Regency. Students got some material of human rights only limited to theories on civics and social subject, such as tolerance, mutual respect, polite attitude, honesty and discipline.

The questionnaire result of human rights knowledge of 40 (forty) elementary school teachers in Kendal Regency were as follow.

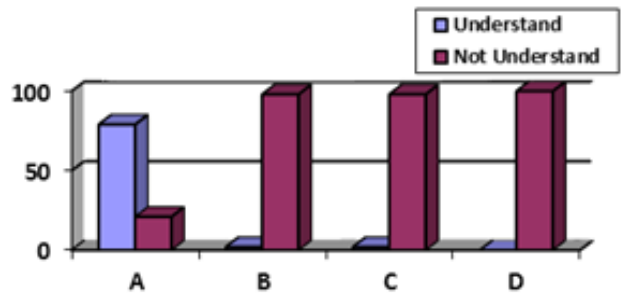

a. Source: Data Process in 2017

Fig. 1. Teacher's Knowledge of Human Rights Education

The questionnaire of human rights education consists of 4 (four) basic items, namely children's rights (A), human rights education (B), implementation of human rights education (C) and children violations (D). Based on Figure 1, only 79\% teachers understood about children's rights and could mention the kinds of children's right, while $21 \%$ did not understand (A); the number of $98 \%$ teachers did not understand about human rights education (B) and the implementation at school (C) and 100\% teachers did not understand about children's violations (D).

Eckmann stated, human rights education is a tool for raising human rights awareness [9]. Bokova and Pillay states human rights education should be established as education and activities in daily life [10]. Human rights education was not an element of curriculum
The review of head of education office were a) simple language; b) short film duration; c) manual book for user guide. The review of animator were a) detail attributes and equipment's in every scane taken; b) color selection in character; c) humor.

This study used UNICEF curriculum as reference and adjusted it with ideology, philosophy and issues. Model of human rights education focused on age, constituency, national politics, generation rights and ideology. Nasution noted, every child grows up in line with his age [11]

According to Preez, to get the maximum result, the curriculum and learning method should be created in different context [12]. Scott stated, the most effective of human rights education implementation is separated approach [13]. Rivet and Krajcik stated, human rights education material could be integrated with other subject [14]. Vieira de Mello noted, the most effective in implementing human rights education is through extracurricular [15]. Jerald stated, human rights education should be integrated with hiden curriculum [16]. This study integrated human rights education with other subject, namely civic and social subject with animation as learning media.

The use of multimedia as a learning media is profitable to promote active learning, critical learning, motivation, flexibility for students with special needs, cooperative learning, communication skill, multisensory delivery and multicultural education. Wyk stated, cartoon is a learning media that can be used to enhance constructive, cooperative and collaborative learning [6]. Eker and Karadeniz stated, cartoon is a learning media to improve students' achievement [7].

This study was started with homogeneity test for all respondents. The result of $\mathrm{F}$ count in homogeneity test was $1.13, \mathrm{df}=19$ and $\mathrm{F}$ table was $2.17, \mathrm{P}=0.05$. $\mathrm{F}$ count $<\mathrm{F}$ table $(1.13<2.17)$. It could be concluded that respondents chosen were homogen in human rights education.

Pretest was conducted both for control group and experiment group.

TABLE I. The MEAN OF PRETEST

\begin{tabular}{|l|l|l|l|l|l|}
\hline \multicolumn{1}{|c|}{ Group } & $\begin{array}{c}\text { Knowl } \\
\text { edge }\end{array}$ & $\begin{array}{c}\text { Traini } \\
\text { ng }\end{array}$ & $\begin{array}{c}\text { Inform } \\
\text { ation }\end{array}$ & $\begin{array}{c}\text { Aware } \\
\text { ness }\end{array}$ & $\begin{array}{c}\text { Acti } \\
\text { vity }\end{array}$ \\
\hline Control Group & 2.6 & 1.8 & 1.5 & 1.8 & 1.9 \\
\hline $\begin{array}{l}\text { Experiment } \\
\text { Group }\end{array}$ & 3.2 & 1.9 & 1.3 & 1.1 & 1.6 \\
\hline
\end{tabular}

Based on research result on Table I, Respondents from both groups had a low knowledge (2.6 for control group and 3.2 for experiment group), training (1.8 for control group and 1.9 for experiment group), information (1.5 for control group and 1.3 for experiment group), awareness (1.8 for control group and 1.1 for experiment group) and activity of human rights (1.9 for control group and 1.6 for experiment group). The experiment group received treatment, namely the respondents received human rights education material in animation film for 8 (eight) times. 
The posttest was conducted for 2 (two) groups both control group and experiment group. The result of posttest was as follow.

TABLE II. THE MEAN OF POSTTEST

\begin{tabular}{|l|l|l|l|l|l|}
\hline \multicolumn{1}{|c|}{ Group } & $\begin{array}{c}\text { Know } \\
\text { ledge }\end{array}$ & $\begin{array}{c}\text { Trai } \\
\text { ning }\end{array}$ & $\begin{array}{c}\text { Informat } \\
\text { ion }\end{array}$ & $\begin{array}{c}\text { Awa } \\
\text { rene } \\
\text { Ss }\end{array}$ & $\begin{array}{c}\text { Acti } \\
\text { vity }\end{array}$ \\
\hline $\begin{array}{l}\text { Control } \\
\text { Group }\end{array}$ & 3.20 & 2.05 & 1.60 & 1.95 & 3.50 \\
\hline $\begin{array}{l}\text { Experiment } \\
\text { Group }\end{array}$ & 11.05 & 5.00 & 8.40 & 3.65 & 7.05 \\
\hline
\end{tabular}

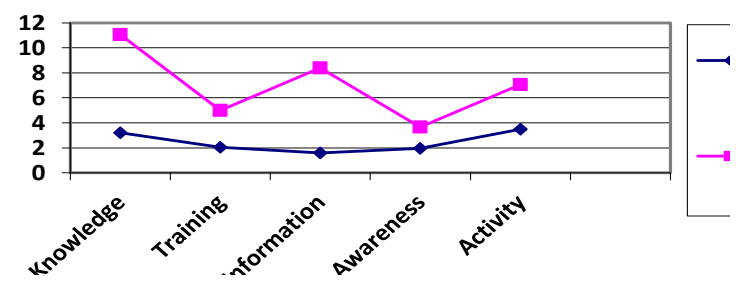

Fig. 2. The mean of posttest.

The respondents in experiment group showed better in knowledge, training, information, awareness and activity after getting human rights education material.

The $t$ test was conducted to know the success rate of human rights education. The $t$ count in this study was 15.577 , while $t$ critical was 1.729 . The $t$ critical was obtained from $\mathrm{df}=1.729$, $\mathrm{P}=0.05$. Based on the result of $\mathrm{t}$ test, it could be concluded that there was significant different between pretest and posttest.

This study used N-Gain as analysis tool. The N-Gain score was divided into 5 (five) section.

- The N-Gain score of knowledge was 0.726. Knowledge section taught about knowledge, understanding, attitude and adaptation to environment. That human rights education is education that can enhance learners' capacity to have a sense of mutual respect, protect and fulfill the rights of others.

- The N-Gain score of information was 0.811 . Information section taught about knowledge, reduced uncertainty of information and unnecessary diversity, provided standards and rules and decision making to determine achievement.

- The N-Gain score of training was 0.749. Training section taught about appropriate action, ability and attitude. Eckmann said, learners should be able to behave in human rights respect [7].

- The N-Gain score of awareness was 0.662. Awareness section taught about knowledge, understanding, attitude and behaviour pattern. In the child's cognitive development, each child has his or her own way of interpreting and adapting to the environment.
- The N-Gain score of activity was 0.852. Activity section taught about visual, oral, listening, drawing, writing, motor, mental and emotional activities.

The implementation of human rights education in elementary school used integrated approach, namely integration between human rights education material with civic and social subject. Teachers combined the material of human rights education and subject material. In terms of integrated learning, both material human rights education material and subject material not limited on theory, but also knowledge, information, training, awareness and activity to promote universal human rights respect.

\section{CONCLUSION}

Human rights education model used curriculum from UNICEF as reference and adjusted it with ideology, philosophy and issues. The new thing in this research was developing human rights education model in line with ideology, philosophy and issues in Indonesia.

\section{REFERENCES}

[1] M. Dziva, S. Bhebhe, and C. Maphosa, "Procedia Social and Behavioral Sciences International Conference on Education and Educational Psychology (ICEEPSY 2010) Education in Terms of Human Rights Simone Emmert, LL.M.Eur.12, pp. 346-361, 2011.

[2] Mohajan, K. Haradhan, "Child Rights in Bangladesh," Journal of Social Welfare and Human Rights, vol. 2, No.1, pp. 207-238, March 2014.

[3] T. Thilagavathy, Kuchy, A. Sheeraz, "Human Rights Education In India: Importance, Present Status And Future Actions," Asia Pacific Journal of Research, pp.120-125, 2015.

[4] Skinner, F. Burrhus, Pendidikan di Walden Two Dalam Menggugat Pendidikan; Fundamentalis, Konservatif, Liberal, Anarkis, terjemahan Omi Intan Noami, Cetakan ketujuh, Yogyakarta: Pustaka Pelajar, 2009.

[5] Rahyubi, Heri, Teori-teori Belajar dan Aplikasi Pembelajaran Motorik, Bandung: Referens, 2012

[6] Wyk, M. Michael, Van, "The Use of Cartoons as a Teaching Tool to Enhance Student Learning in Economic Education,” J. Soc. Sci, vol. 26, no.2, pp. 117-130, 2011.

[7] Eker, Cevat, dan Karadeniz, Oguzhan, "The Effect of Educational Practice With Cartoons on Learning Outcomes," International Journal of Humanities and Social Science, vol. 4, No.14, pp. 143-154, 2014.

[8] Jennings, Todd, "Human Rights Education Standards for Teachers and Teacher Education," Routledge Teaching Education, vol. 17, No.4, pp. 287-298, 2006.

[9] M. Eckmann, A. Scherr, H. Zimmer, and K.P. Fritzshe, "History and Human Rights Education: A Challenge for Education," 2009.

[10] I. Bokovo, and N. Pillay, World Programme for Human Rights Education, Second Phase Plan of Action, Geneva: United Nations Office of the High Commission, 2012.

[11] S. Nasution, Asas-Asas Kurikulum, Jakarta: Bumi Aksara, 2014.

[12] Du Preez, Petro, S. Simmonds, and R. Cornelia, "Teaching-learning and curriculum development for human rights education: Two sides of the same coin," Journal of Education, vol. 55, No. 1, pp. 84-103, 2012.

[13] D. Scott, Critical Essays on Major Curriculum Theorists, London: Routledge, 2008.

[14] A.E. Rivet, and J.S. Krajcik, "Contextualising instruction: Leveraging students' prior knowledge and experiences to foster understanding of middle school science," Journal of Research in Science Teaching, vol. 45, No.1, pp. 79-100, 2008. 
[15] Vieira de, S. Mello, Teaching Human Rights: Practical Activities for Primary and Secondary Schools, United Nations: New York, 2004.
[16] Jerald, and D. Craig, School Culture: The Hidden Curriculum, 2006. 